\title{
Epidemiology of basal cell carcinomas and squamous cell carcinomas in a Department of Dermatology - a 5 year review
} Epidemiologia dos carcinomas basocelulares e espinhocelulares em um Serviço de Dermatologia - revisão de 5 anos

\author{
Pedro Andrade ${ }^{1}$ \\ Ricardo Vieira ${ }^{2}$ \\ José Pedro Reis ${ }^{3}$ \\ Américo Figueiredo ${ }^{5}$
}

\author{
Maria Manuel Brites ${ }^{2}$ \\ Angelina Mariano ${ }^{3}$ \\ Oscar Tellechea ${ }^{4}$
}

\begin{abstract}
BACKGROUND: Non-melanoma skin cancer, a common designation for both basal cell carcinomas and squamous cell carcinomas, is the most frequent malignant skin neoplasm.

OBJECTIVE: Epidemiologic characterization of the population with Non-melanoma skin cancer.

METHODS: Retrospective analysis of all patients diagnosed with Non-melanoma skin cancer based on histopathologic analysis of all incisional or excisional skin biopsies performed between 2004 and 2008 in a Department of Dermatology.

Results: A total of 3075 Non-melanoma skin cancers were identified, representing $88 \%$ of all malignant skin neoplasms $(\mathrm{n}=3493)$ diagnosed in the same period. Of those, $68,3 \%$ were basal cell carcinomas. Most Non-melanoma skin cancer patients were female and over 60 years old. Of all Non-melanoma skin cancer, $81,7 \%(n=1443)$ were located in sun-exposed skin, and represented 95,1\% of malignant skin neoplasms in sun-exposed skin. Non-melanoma skin cancer was the most frequent malignant skin neoplasm in most topographic locations, except for abdomen and pelvis - over $95 \%$ of all malignant skin neoplasms in the face, neck and scalp were Non-melanoma skin cancer. Basal cell carcinomas were clearly predominant in all locations, except in upper and lower limbs, lower lip and genitals, where squamous cell carcinomas represented respectively $77,7 \%, 77,4 \%, 94,7 \%$ and $95,3 \%$ of the Non-melanoma skin cancers.

Conclusion: Being the most common skin cancer, Non-melanoma skin cancer should be under constant surveillance, in order to monitor its epidemiologic dynamics, the efficiency of preventive measures and the adaptation of the healthcare resources.

Keywords: Carcinoma, basal cell; Carcinoma, squamous cell; Neoplasms; Skin neoplasms
\end{abstract}

Resumo: FunDAMENTOS: O cancro cutâneo não-melanoma, designação conjunta para os carcinomas basocelulares e espinhocelulares, é o tipo de neoplasia cutânea maligna mais frequente.

OBJETTVOS: Caracterização epidemiológica da população diagnosticada com cancro cutâneo não-melanoma.

MÉToDos: Foi realizada uma análise retrospectiva dos doentes portadores de cancro cutâneo não-melanoma identificados por análise histológica de todas as biopsias cutâneas incisionais ou excisionais ao longo de 5 anos (2004-2008) num serviço de Dermatologia.

RESULTADOS: foram identificados 3075 cancros cutâneos não-melanoma, representando $88 \%$ do total de neoplasias malignas diagnosticadas no mesmo período $(n=3493)$. Destes, $68,3 \%$ eram carcinomas basocelulares. No seu conjunto, a população de cancro cutâneo nãomelanoma era predominantemente constituída por indivíduos idosos e do sexo feminino, tendo sido observado um aumento consistente da freqüência ao longo do período avaliado (5,25\%/ano). A maioria dos cancros cutâneos não-melanoma ( $\mathrm{n}=1443,81,7 \%$ ) foi identificada nas áreas de pele foto-exposta, representando $95,1 \%$ de todas as neoplasias malignas em áreas foto-expostas. O cancro cutâneo não-melanoma foi a neoplasia mais representativa na generalidade das áreas topográficas, à exceção do abdômen e da pélvis, representando, em particular, mais de 95\% das neoplasias malignas da face, da região cervical e do couro cabeludo. O carcinoma basocelular foi o cancro cutâneo não-melanoma predominante em todas as localizações, à exceção dos membros inferiores e superiores, lábio inferior e da área genital, onde o carcinoma espinhocelular representou, respectivamente, 77,7\%, 77,4\%, 94,7\% e 95,3\% dos casos.

CONCLusôES: O cancro cutâneo não-melanoma, como neoplasia maligna cutânea mais freqüente, deverá ser alvo de uma monitorização regular, com vista à determinação da sua dinâmica epidemiológica, da eficácia das medidas preventivas e adequação dos recursos de saúde.

Palavras-chave: Carcinoma basocelular; Carcinoma de células escamosas; Neoplasias; Neoplasias cutâneas

Received on 20.06.2011

Approved by the Advisory Board and accepted for publication on 25.07.2011

$*$ Work performed at the Dermatology and Venereology Service of the Universidade de Coimbra, EPE - Coimbra, Portugal.

Financial Support: None.

Conflict of Interests: None.

M.D. - Médico Interno de Dermatologia e Venereologia - Serviço de Dermatologia e Venereologia, Hospitais da Universidade de Coimbra, EPE - Coimbra, Portugal.

M.D. - Médica Especialista em Dermatologia e Venereologia - Assistente Hospitalar - Serviço de Dermatologia e Venereologia, Hospitais da Universidade de Coimbra, EPE - Coimbra, Portugal.

M.D. - Médica Especialista em Dermatologia e Venereologia - Assistente Hospitalar Graduado (a) - Serviço de Dermatologia e Venereologia, Hospitais da Universidade de Coimbra, EPE - Coimbra, Portugal.

Ph.D. - Professor doutor - Médico Especialista em Dermatologia e Venereologia - Chefe de Serviço - Serviço de Dermatologia e Venereologia, Hospitais da Universidade de Coimbra, EPE - Coimbra, Portugal.

Ph.D - Professor doutor - Médico Especialista em Dermatologia e Venereologia - Director do Serviço de Dermatologia e Venereologia - Hospitais da Universidade de Coimbra, EPE - Coimbra, Portugal. 


\section{INTRODUCTION}

Malignant cutaneous neoplasms consist in a highly heterogeneous group of diseases with variable courses and prognosis. These malignant neoplasms are, in its whole, very common and therefore timeconsuming in the general practice of most dermatologists, requiring in several cases a large amount of human and technical resources, such as complex surgical procedures, radiologic exams and regular surveillance routines.

Basal cell carcinoma (BCC) is clearly the most frequent malignant neoplasm in white-skinned individuals, followed by squamous cell carcinoma (SCC) ${ }^{1-6}$ Sharing the same precursor cell, the keratinocyte, BCC are typically locally invasive tumors with virtually no metastatic risk, while SCC are potentially aggressive, metastatic and lethal tumors. Despite being widely recognized as the most common skin tumors, their exact incidence and prevalence in humans have not been clearly established and are far from being consensual: this is due not only to the significant frequency variation observed when considering populations with different phototypes and geographic locations, but also to the misleading oncologic records that, in most countries, have not discriminated SCC from BCC for several years. In fact, for statistical purposes, SCC and BCC have been commonly considered under the same denomination: non-melanoma skin cancer (NMSC). ${ }^{2,3,5}$

Multiple risk factors have been described for NMSC, but chronic exposure to ultraviolet radiation, particularly UV-B, is clearly the most important, progressively inducing keratinocyte carcinogenesis and resulting in BCC or SCC after several years or decades of cumulative cellular degeneration. $2,3,6,7,8$ However, BCC and SCC do not arise randomly in a chronically sun-exposed skin as the pattern of UV exposure seems to play a role: many studies have shown that SCC is frequently associated with long term chronic UV-exposure, while BCC is associated with intense intermittent UV-exposure. ${ }^{2,5,6}$ The reason why these two patterns of sun-exposure seem to act differently in the skin has not been identified yet.

Apart from the duration and intensity of UV exposure, other factors may facilitate the development of NMSC, such as lower phototypes (light skin, hair and eyes), temporary or long term permanence in high altitude or low latitude locations or outdoor professional or recreational activities, especially in young individuals and without sun protective clothing and precautions. ${ }^{1,2}$ Additionally, iatrogenic or cosmetic artificial UV skin irradiation, exposure to ionizing radiation or other carcinogenic agents in the environment and immunesuppression may also increase the risk of NMSC in some particular cases. ${ }^{1-8}$ In what concerns the SCC, smoking and oncogenic HPV infection have also been identified as important risk factors, particularly for the perioral and genital areas. ${ }^{6}$ Some rare genodermatosis such as xeroderma pigmentosum, oculocutaneous albinism, epidermodysplasia verruciformis and Gorlin-Glotz syndrome, may also be associated with some cases of NMSC. ${ }^{6,7}$ The role of sunscreens remains controversial - the regular use of sunscreens seems to be effective in the prevention of actinic keratosis and SCC but not BCC, and some studies have even suggested that inducing an excessive sense of sun protection might lead to negligent sun exposure behaviors and somehow raise the risk of BCC or malignant melanoma, particularly if using low SPF sunscreens lacking a broad UV-A protection. ${ }^{5,9}$

In response to the high incidence of NMSC, many awareness campaigns focusing on preventive behaviors concerning major avoidable risk factors have been launched in previous years. Despite the effort, no significant effects on the worldwide continuously raising NMSC incidence have been observed. ${ }^{2,4,6,7,10,11,12}$ This tendency keeps challenging the health care systems, imposing a continuous adaptation of the available resources based on a rigorous epidemiologic surveillance.

\section{METHODS}

The study consisted in a retrospective and descriptive analysis of all patients diagnosed with BCC or SCC, based on the histopathologic analysis of all incisional or excisional skin biopsies performed between 2004 and 2008 in our Department of Dermatology. Biopsies showing recurrence or persistence of previously diagnosed neoplasms were excluded. All patients were characterized according to their age, sex, type of malignant neoplasm (BCC, invasive SCC and in situ SCC) and its location.

Concerning neoplasm location, eleven skin areas were considered, as follows: face, scalp, neck, chest, abdomen, dorsum, lumbar area, pelvis, genital area, upper limbs and lower limbs. For comparative purposes, face was divided into several topographic areas, including forehead, nose, cheek, zygomatic prominence, upper eyelid, lower eyelid, inner eye canthus, mandibular area, upper lip, lower lip and ear. Similarly, limbs were also divided into proximal, medium and distal segments - the considered segments respectively correspond in the upper limb to arm/shoulder, forearm/elbow and hand/wrist, and in the lower limb to thigh, leg/knee and foot/ankle.

Sun-exposed skin was defined as corresponding to the face (including ears), neck, elbows, forearms, wrists and hands, representing approximately $16 \%$ of the total skin surface. 
Statistical analysis of all data was performed using SPSS version 19.0, using Chi Square and Fisher's Exact Tests. Statistical significance for variables relationship was considered when $p<0,05$.

\section{RESULTS}

A total number of 3493 malignant cutaneous neoplasms were diagnosed in our Department in the considered 5-year period. During this time, 99.311 consultations were conducted, revealing a ratio of 1 new diagnosis of malignant cutaneous neoplasm for every 28,4 consultations. Most of these malignant neoplasms were diagnosed in female patients $(52,4 \%$, $n=1832)$, and the remaining $47,6 \%(n=1661)$ in male patients. The average age of the whole population was $70,8( \pm 13,8)$ years old, being $71,6 \pm 14,2$ years old for female patients and 70,1 $\pm 22,1$ years old for males; $80,3 \%$ of all patients were aged over 60 , and $58,1 \%$ over 70 .

Among all malignant cutaneous neoplasms, BCC and SCC were clearly the most common, respectively representing $60,1 \%(\mathrm{n}=2100)$ and $27,9 \%$ $(n=975)$ of all tumors - table 1 . Therefore, NMSC corresponded to $88 \%(n=3075)$ of all malignant cutaneous neoplasms. Malignant melanoma was identified in $6,4 \%(n=225)$ of all skin biopsies, followed by malignant lymphoproliferative disorders $(1,8 \%$, $\mathrm{n}=63)$, cutaneous metastasis $(1,7 \%, \mathrm{n}=60)$, Kaposi sarcoma $(0,7 \%, n=23)$, dermatofibrosarcoma $(0,3 \%$, $\mathrm{n}=11)$, malignant adnexal tumors $(0,3 \%, \mathrm{n}=9)$, Merkel cell carcinoma $(0,1 \%, n=2)$ and other neoplasms $(0,7 \%, \mathrm{n}=25)$.

\section{Basal cell carcinoma}

Most BCC were diagnosed on female patients $(53,8 \%, n=1131)$ revealing a statistically significant association $(\mathrm{p}=0,04)$. The average age of this group was $70,3( \pm 13,6)$ years old, showing no variation when considering only male $(70,6 \pm 12,8$ years old) or female patients $(70,0 \pm 14,2$ years old). These results clearly demonstrate the predominance of elderly patients ( $p<0,001$ for age $>70$ years), as only $19,8 \%$ of the patients were aged 60 or less at the time of diagnosis.

The great majority of BCC were identified on the face $(n=1321,62,9 \%)$ - table 1 . Of those, $29,4 \%$ $(n=388)$ were on the nose, $21,4 \%(n=283)$ on the zygomatic prominence and $14,7 \%(n=194)$ on the forehead. The remaining $\mathrm{BCC}$ were located on the cheek $(n=114,8,6 \%)$, the inner eye canthus $(n=98$, $7,4 \%)$, the ear $(n=64,4,8 \%)$, the upper lip $(n=53$, $4,0 \%)$, the mandibular region $(n=45,3,4 \%)$, the lower eyelid $(n=43,3,3 \%)$, the upper eyelid $(n=6,0,4 \%)$ and the lower lip $(n=5,0,4 \%)$. BCC location within the face was not specified in 28 cases $(2,1 \%)$.

Excluding the face, the scalp was the skin area where most BCC were diagnosed $(n=379,18,0 \%)$, followed by the neck $(n=98,4,7 \%)$, dorsum $(n=90$, $4,3 \%)$, chest $(n=67,3,2 \%)$, upper $\operatorname{limb}(n=45,2,1 \%)$, lower limb $(n=35,1,7 \%)$, lumbar area $(n=29,1,4 \%)$, abdomen $(n=20,0,9 \%)$, pelvis $(n=6,0,3 \%)$ and genital area $(n=2,0,1 \%)$. BCC location was not specified in the 8 remaining cases $(0,4 \%)$. Concerning the upper limb, $46,7 \%$ of BCC $(n=21)$ were located proximally, $40,0 \%(n=18)$ on the medium segment and $13,3 \%(n=6)$ distally; on the lower limb, most BCC $(91,4 \%, n=32)$ were located on the medium segment, $5,7 \%(n=2)$ on the proximal segment and $2,9 \%(n=1)$ on the distal segment.

Sex distribution was not homogeneous for each BCC location (Chart 1). Female sex predominance was statistically significant on the nose $(p=0,01)$, the upper lip $(p=0,005)$ and the lower eyelid $(p=0,02)$. However, a statistically significant association was found between male sex and some BCC locations, such as the chest $(p=0,001)$, the dorsum $(p=0,03)$ and the zygomatic prominence $(\mathrm{p}<0,001)$, opposing the tendency observed for the general BCC population.

More than half of all BCC's $(68,8 \%, n=1443)$ were located on sun-exposed skin areas - table 1 -, revealing a statistically significant association $(\mathrm{p}<0,001)$.

\section{Squamous Cell Carcinoma}

Most patients diagnosed with SCC were male $(\mathrm{n}=495,50,8 \%)$, but this predominance was not statistically significant $(p=0,52)$. The average age of the group was $74,4 \pm 12,4$ years old. Male patients were slightly younger $(71,3 \pm 13,3$ years old) than female patients $(78,8 \pm 10,1$ years old). Only $13 \%$ of SCC patients were aged 60 or less, and elder patients predominance was statistically significant $(\mathrm{p}<0,001$ for age $>60$ and $>70$ years).

Nearly a quarter of all diagnosed SCC $(n=251$, $25,7 \%)$ were histologically classified as in situ. The average age of patients diagnosed with SCC in situ was not statistically different from the general population's $(72,7 \pm 12,1$ years old), being $70,1 \pm 12,7$ years old for male patients and $74,7 \pm 11,3$ years old for female patients.

Most SCC were located on the face $(n=506$, $51,9 \%)$ - table 1 -, particularly on the zygomatic prominence $(n=157,31 \%)$, the lower lip $(n=90,17,8 \%)$, the ear $(n=59,11,7 \%)$, the forehead $(n=58,11,5 \%)$ and the nose $(n=51,10,1 \%)$. The remaining SCC were identified on the mandibular region $(n=32,6,3 \%)$, the cheek $(n=22,4,4 \%)$, the upper lip $(n=4,0,8 \%)$, the lower eyelid $(n=4,0,8 \%)$, the inner eye canthus $(n=3,0,6 \%)$ and the upper eyelid $(n=1,0,2 \%)$. In $4,9 \%$ of the facial SCC $(n=25)$ the exact location was not specified. 
TABLE 1: BCC and SCC distribution by age, sex and topographic area, in the context of NMSC population and total skin malignant neoplasm population diagnosed between 2004 and 2008. IBCC absolute frequency; IIBCC percentage in relation to total BCC population; IIISCC absolute frequency; IVSCC percentage in relation to total SCC population; VNMSC absolute frequency; VINMSC percentage in relation to total NMSC population; VIIBCC percentage in relation to total NMSC population; VIIIMalignant cutaneous neoplasm absolute frequency; IXMalignant cutaneous neoplasm percentage in relation to total skin malignancies population; XCCNM percentage in relation to total skin malignancies population

\begin{tabular}{|c|c|c|c|c|c|c|c|c|c|c|}
\hline & BCC $^{\mathrm{I}}$ & $\% \mathrm{BCC}^{\mathrm{II}}$ & SCC $^{\mathrm{III}}$ & $\% \mathrm{SCC}^{\mathrm{IV}}$ & NMSC $^{\mathrm{V}}$ & \%NMSC ${ }^{\mathrm{VI}}$ & $\% \mathrm{BCC}^{\mathrm{VII}}$ & TOTAL ${ }^{\mathrm{VII}}$ & \% TOTAL ${ }^{\mathrm{IX}}$ & \%NMSC ${ }^{\mathrm{x}}$ \\
\hline $\begin{array}{l}\text { Total } \\
\text { SEX }\end{array}$ & 2100 & $100,0 \%$ & 975 & $100,0 \%$ & 3075 & $100,0 \%$ & $68,3 \%$ & 3493 & $100,00 \%$ & $88,0 \%$ \\
\hline Male & 969 & $46,2 \%$ & 495 & $50,8 \%$ & 1464 & $47,6 \%$ & $66,2 \%$ & 1661 & $47,56 \%$ & $88,1 \%$ \\
\hline $\begin{array}{l}\text { Female } \\
\text { AGE (years) }\end{array}$ & 1131 & $53,8 \%$ & 480 & $49,1 \%$ & 1611 & $52,4 \%$ & $70,2 \%$ & 1832 & $52,44 \%$ & $87,9 \%$ \\
\hline $0-10$ & 0 & $0,0 \%$ & 0 & $0,0 \%$ & 0 & $0,0 \%$ & - & 1 & $0,03 \%$ & $0,0 \%$ \\
\hline 11.20 & 0 & $0,0 \%$ & 0 & $0,0 \%$ & 0 & $0,0 \%$ & - & 2 & $0,06 \%$ & $0,0 \%$ \\
\hline $21-30$ & 37 & $1,8 \%$ & 7 & $0,7 \%$ & 44 & $1,4 \%$ & $84,1 \%$ & 59 & $1,69 \%$ & $74,6 \%$ \\
\hline $31-40$ & 27 & $1,3 \%$ & 15 & $1,5 \%$ & 42 & $1,4 \%$ & $64,3 \%$ & 64 & $1,83 \%$ & $65,6 \%$ \\
\hline $41-50$ & 103 & $4,9 \%$ & 25 & $2,6 \%$ & 128 & $4,2 \%$ & $80,5 \%$ & 168 & $4,81 \%$ & $76,2 \%$ \\
\hline $51-60$ & 248 & $11,8 \%$ & 80 & $8,2 \%$ & 328 & $10,7 \%$ & $75,6 \%$ & 385 & $11,02 \%$ & $85,2 \%$ \\
\hline $61-70$ & 504 & $24,0 \%$ & 182 & $18,7 \%$ & 686 & $22,3 \%$ & $73,5 \%$ & 773 & $22,13 \%$ & $88,7 \%$ \\
\hline $71-80$ & 682 & $32,5 \%$ & 329 & $33,7 \%$ & 1011 & $32,9 \%$ & $67,5 \%$ & 1130 & $32,35 \%$ & $89,5 \%$ \\
\hline $81-90$ & 442 & $21,1 \%$ & 291 & $29,9 \%$ & 733 & $23,8 \%$ & $60,3 \%$ & 803 & $22,99 \%$ & $91,3 \%$ \\
\hline $91-100$ & 47 & $2,2 \%$ & 45 & $4,6 \%$ & 92 & $3,0 \%$ & $51,1 \%$ & 97 & $2,78 \%$ & $94,8 \%$ \\
\hline $\begin{array}{l}\text { Not specified } \\
\text { SKIN LOCATION }\end{array}$ & 10 & $0,5 \%$ & 1 & $0,1 \%$ & 11 & $0,3 \%$ & $90,9 \%$ & 11 & $0,31 \%$ & $100,0 \%$ \\
\hline Face & 1321 & $62,9 \%$ & 506 & $51,9 \%$ & 1827 & $59,6 \%$ & $72,3 \%$ & 1906 & $54,6 \%$ & $95,9 \%$ \\
\hline Forehead & 194 & $14,7 \%$ & 58 & $11,5 \%$ & 252 & $13,8 \%$ & $77,0 \%$ & & & \\
\hline Nose & 388 & $29,4 \%$ & 51 & 10,1 & 439 & $24,0 \%$ & $88,4 \%$ & & & \\
\hline $\begin{array}{l}\text { Zygomatic } \\
\text { prominence }\end{array}$ & 283 & $21,4 \%$ & & 157 & $31,0 \%$ & 440 & $24,1 \%$ & $64,3 \%$ & & \\
\hline Cheek & 114 & $8,6 \%$ & 22 & $4,4 \%$ & 136 & $7,4 \%$ & $83,8 \%$ & & & \\
\hline Mandibular region & 45 & $3,4 \%$ & 32 & $6,3 \%$ & 77 & $4,2 \%$ & $58,4 \%$ & & & \\
\hline Upper eyelid & 6 & $0,4 \%$ & 1 & $0,2 \%$ & 7 & $0,4 \%$ & $85,7 \%$ & & & \\
\hline Lower eyelid & 43 & $3,3 \%$ & 4 & $0,8 \%$ & 47 & $2,6 \%$ & $91,5 \%$ & & & \\
\hline Inner eye canthus & 98 & $7,4 \%$ & 3 & $0,6 \%$ & 101 & $5,5 \%$ & $97,0 \%$ & & & \\
\hline Upper lip & 53 & $4,0 \%$ & 4 & $0,8 \%$ & 57 & $3,1 \%$ & $93,0 \%$ & & & \\
\hline Lower lip & 5 & $0,4 \%$ & 90 & $17,8 \%$ & 95 & $5,2 \%$ & $5,3 \%$ & & & \\
\hline Ear & 64 & $4,8 \%$ & 59 & $11,7 \%$ & 123 & $6,7 \%$ & $52,0 \%$ & & & \\
\hline Not specified & 28 & $2,1 \%$ & 25 & $4,9 \%$ & 53 & $2,9 \%$ & $52,8 \%$ & & & \\
\hline Scalp & 379 & $18,0 \%$ & 81 & $8,3 \%$ & 460 & $15,0 \%$ & $82,4 \%$ & 485 & $13,9 \%$ & $94,8 \%$ \\
\hline Neck & 98 & $4,7 \%$ & 40 & $4,1 \%$ & 138 & $4,5 \%$ & $71,0 \%$ & 146 & $4,2 \%$ & $94,5 \%$ \\
\hline Chest & 67 & $3,2 \%$ & 11 & $1,1 \%$ & 78 & $2,6 \%$ & $85,9 \%$ & 107 & $3,1 \%$ & $72,9 \%$ \\
\hline Dorsum & 90 & $4,3 \%$ & 4 & $0,4 \%$ & 94 & $3,1 \%$ & $95,7 \%$ & 133 & $3,8 \%$ & $70,7 \%$ \\
\hline Abdomen & 20 & $0,9 \%$ & 2 & $0,3 \%$ & 22 & $0,7 \%$ & $90,9 \%$ & 47 & $1,3 \%$ & $46,8 \%$ \\
\hline Lumbar area & 29 & $1,4 \%$ & 2 & $0,3 \%$ & 31 & $1,0 \%$ & $93,5 \%$ & 37 & $1,1 \%$ & $83,8 \%$ \\
\hline Pelvis & 6 & $0,3 \%$ & 1 & $0,1 \%$ & 7 & $0,2 \%$ & $85,7 \%$ & 23 & $0,6 \%$ & $30,4 \%$ \\
\hline Genital area & 2 & $0,1 \%$ & 41 & $4,2 \%$ & 43 & $1,4 \%$ & $4,7 \%$ & 49 & $1,4 \%$ & $87,8 \%$ \\
\hline Upper limb & 45 & $2,1 \%$ & 154 & $15,7 \%$ & 199 & $6,2 \%$ & $22,6 \%$ & 237 & $6,8 \%$ & $84,0 \%$ \\
\hline Shoulder/Arm & 21 & $46,7 \%$ & 11 & $7,2 \%$ & 32 & $16,1 \%$ & $67,7 \%$ & & & \\
\hline Elbow/Forearm & 18 & $40,0 \%$ & 31 & $20,1 \%$ & 49 & $24,6 \%$ & $36,7 \%$ & & & \\
\hline Wrist/Hand & 6 & $13,3 \%$ & 112 & $72,7 \%$ & 118 & $59,3 \%$ & $5,0 \%$ & & & \\
\hline Lower limb & 35 & $1,7 \%$ & 122 & $12,5 \%$ & 157 & $5,1 \%$ & $22,3 \%$ & 274 & $7,8 \%$ & $57,3 \%$ \\
\hline Thigh & 2 & $5,7 \%$ & 1 & $0,8 \%$ & 3 & $1,9 \%$ & $66,7 \%$ & & & \\
\hline Knee/Leg & 32 & $91,4 \%$ & 100 & $82,0 \%$ & 132 & $84,1 \%$ & $24,2 \%$ & & & \\
\hline Ankle/Foot & 1 & $2,9 \%$ & 21 & $17,2 \%$ & 22 & $14,0 \%$ & $4,5 \%$ & & & \\
\hline Not specified & 8 & $0,4 \%$ & 11 & $1,1 \%$ & 19 & $0,6 \%$ & $42,1 \%$ & 49 & $1,4 \%$ & $38,8 \%$ \\
\hline $\begin{array}{l}\text { SUN-EXPOSED } \\
\text { AREAS }\end{array}$ & 1143 & $68,7 \%$ & 689 & $70,7 \%$ & 1832 & $59,6 \%$ & $62,4 \%$ & 2241 & $64,2 \%$ & $95,0 \%$ \\
\hline
\end{tabular}




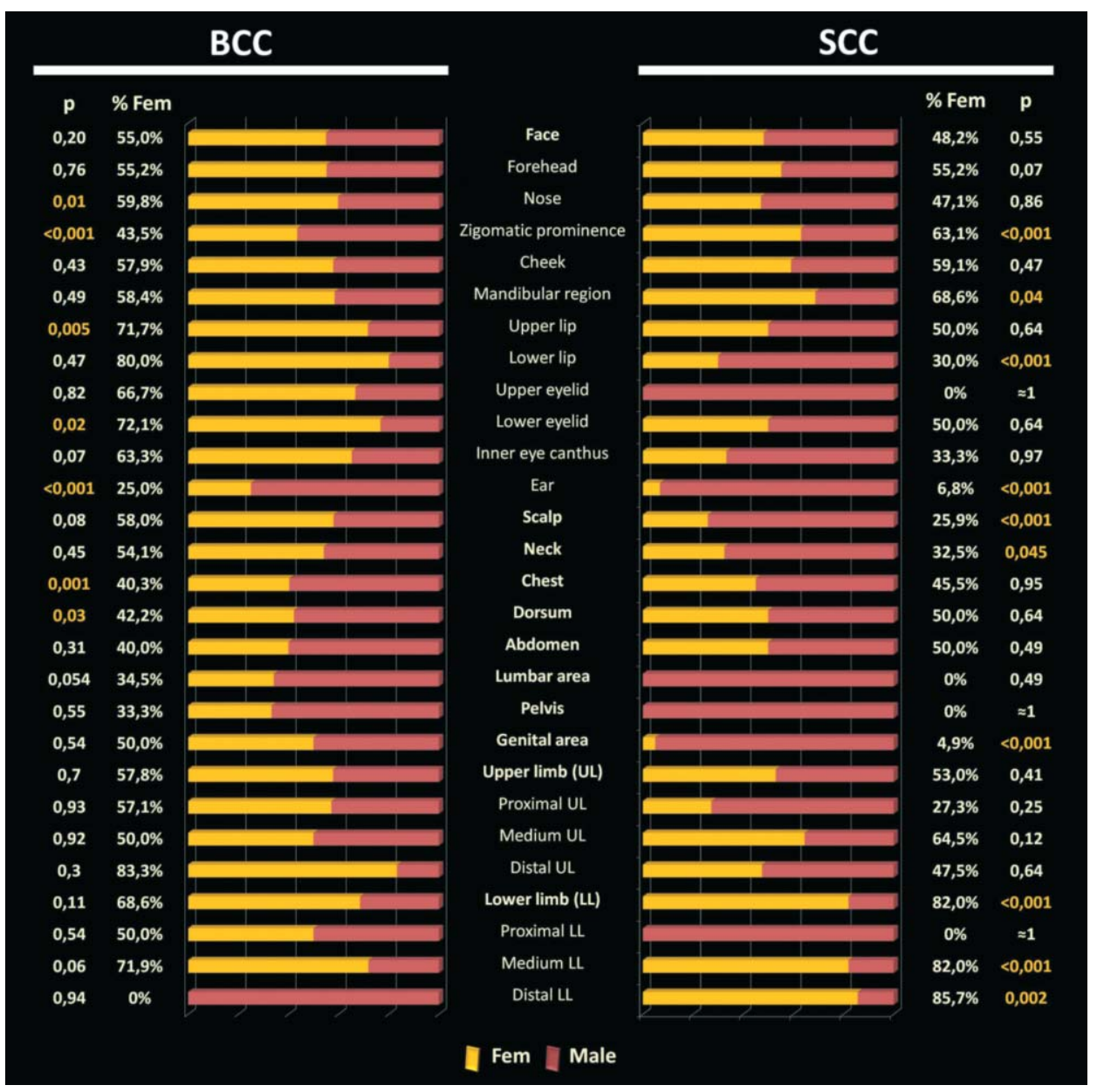

CHART 1 - Sex distribution for BCC and SCC discriminated by topographic areas. \% Fem: female patients' relative frequency; p: p-value
The upper limb was the second most affected skin area $(n=154,15,7 \%)$, followed by the lower limb $(n=122,12,5 \%)$, the scalp $(n=81,8,3 \%)$, the genital area $(n=41,4,2 \%)$ and the neck $(n=40,4,1 \%)$. Of all upper limb SCC, $73,2 \%(n=112)$ were located on the distal segment, $20,3 \%(n=31)$ on the medium segment and 6,5\% $(n=10)$ on the proximal segment. Concerning the lower limb, most SCC $(n=100$, $82,0 \%$ ) were identified on the elbow or the forearm, $17,2 \%(n=21)$ on the hand or wrist and $0,8 \%(n=1)$ on the arm or shoulder.

As observed for BCC, sex distribution was highly variable concerning different locations (Chart 1). Female sex predominance was statistically significant for SCC located on the zygomatic prominence $(p<0,001)$, the mandibular region $(p=0,04)$ and the lower limb $(p<0,001)$, particularly on its medium and distal segments, while male sex was significantly predominant on the lower lip $(p<0,001)$, the ear $(p<0,001)$, the scalp $(p<0,001)$, the neck $(p=0,045)$ and the genital area $(\mathrm{p}<0,001)$.

Additionally, $70,7 \%$ of all SCC $(n=689)$ were located on sun-exposed skin areas, and as for BCC, this association was statistically significant $(p<0,001)$.

\section{Sex distribution}

In what concerns to the whole group of NMSC, a statistically significant female sex predominance was observed $(p=0,04)$.

\section{Topographic distribution}

As described in table 1, most of the 3493 diagnosed malignant cutaneous neoplasms were located on the face $(n=1906,54,6 \%)$ and scalp $(n=485,13,9 \%)$. The remaining tumors were identified on the lower limb $(n=274,7,8 \%)$, the upper limb $(n=237,6,8 \%)$, the neck $(n=146,4,2 \%)$, the dorsum $(n=133,3,8 \%)$, the chest $(n=107,3,1 \%)$, the genital area $(n=49,1,4 \%)$, the abdomen $(n=47,1,3 \%)$, the lumbar area $(n=37,1,1 \%)$, and the pelvis $(n=23,0,6 \%)$. In 49 cases $(1,4 \%)$ the neoplasm location was not discriminated in the clinical records.

NMSC was clearly the most representative malignant skin neoplasm on most areas, particularly on the face, scalp and neck, where respectively $95,9 \%$, $94,8 \%$ and $94,5 \%$ of all malignant skin tumors were NMSC (Table 1). On all other locations NMSC represented over $50 \%$ of all skin malignancies, excluding the abdomen and the pelvis, where only $46,8 \%$ and $30,4 \%$ (respectively) were NMSC. 


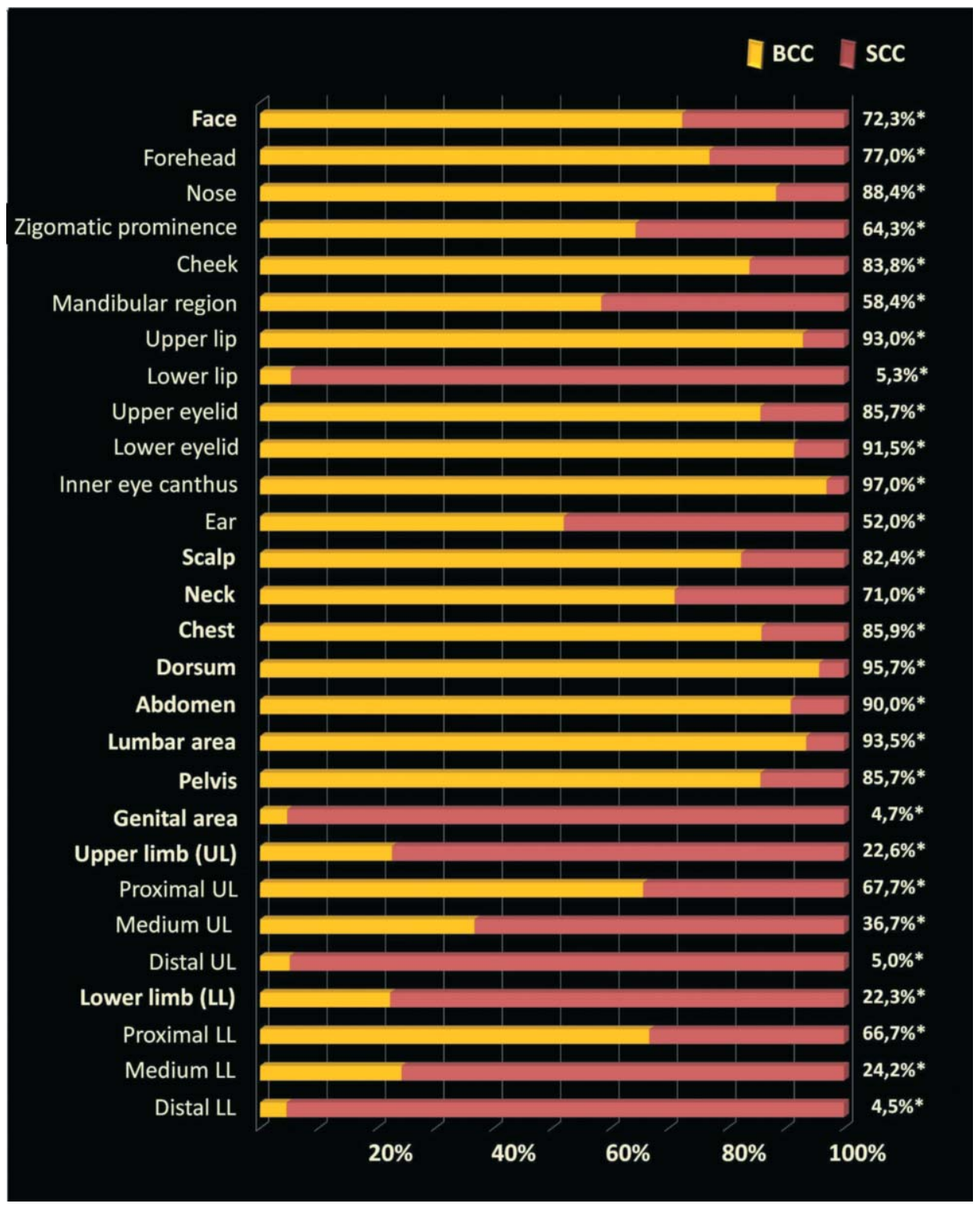

ChART 2 - BCC and SCC relative frequencies for each topographic area. The percentages on the right (*) correspond to BCC
Among NMSC, BCC clearly predominated over SCC on the face, the scalp and all the torso, representing from $71 \%$ to $95,7 \%$ of all NMSC - chart 2 . On the limbs, however, SCC was more frequent than BCC, representing from $76,3 \%$ to $77,7 \%$ of all NMSC. It is noteworthy that $95,1 \%$ of all NMSC on the genital area were SCC. Concerning the face, BCC was predominant on most topographic areas, except the lower lip - chart 2.

\section{Sun-exposed skin areas}

As represented in table 1, 64,2\% of all malignant skin neoplasms $(n=2241)$ were located on sunexposed areas. Similarly, $68,7 \%$ of all BCC $(n=1443)$ and $70,7 \%$ of all SCC $(n=689)$ were diagnosed on sunexposed areas.
This means that NMSC represented $95,1 \%$ of all malignant neoplasms on photo-exposed skin, and, in fact, this association was statistically significant $(\mathrm{p}<0,001)$.

\section{Time course}

A consistent gradual increase of the global frequency of malignant skin neoplasms was observed in our department in the considered period: 628 malignant cutaneous neoplasms were diagnosed in 2004, 662 in 2005, 701 in 2006, 722 in 2007 and 780 in 2008, revealing an average rate of 38 new malignant tumors/year (or 6\%/year).

This tendency was also observed for NMSC, as an average rate of 31,8 new cases were reported every 
year $(5,25 \% /$ year $)$. Concerning BCC, an average rate of 21 new cases/year (5,0\%/year) was observed, while for SCC it was defined as 12,3 new cases/year (6,3\%/year). Even so, the relative frequency of NMSC among all skin malignancies remained unchanged through the studied period. Similarly, no significant changes in BCC/SCC proportion were identified.

\section{DISCUSSION}

These results reflect the reality of Dermatologic Oncology in our department and, as expected, they reproduce the increasing frequency of malignant skin neoplasms observed worldwide. ${ }^{2,4,6,7,10,11,12}$ In fact, this tendency seems to correspond to a real increase in the occurrence of malignant skin tumors, particularly NMSC; however, the interference of factors such as the enhanced access of the general population to specialized care and mass education programs with consequent early diagnosis should not be neglected.

In what concerns the NMSC, the increasing number of diagnosed tumors seems to be clearly connected to the changing habits of sun-exposure occurring in the past decades. ${ }^{2}$ The high number of BCC and SCC diagnosed on sun-exposed skin, and particularly on the face and neck, corroborates the widely accepted association between these neoplasms and long term UV-radiation. ${ }^{2,13}$ In fact, NMSC were the most common malignant skin neoplasms, affecting mainly elderly patients, as previously described ${ }^{14-17}$ In most studies, male sex is reported as predominant, however in our patients the opposite was observed. $6,8,16,18$

BCC represented over two thirds of all NMSC and predominated over SCC on all skin areas, except for the lower lip and the genital area. In the former, SCC predominance is probably explained by its particular anatomic disposition, nearly perpendicular to the solar radiation, potentiating the effect of UV light. Also, the effect of tobacco smoke carcinogens is not negligible. On the genital area the effect of UV radiation is not relevant in most cases, and oncogenic Human Papillomavirus (HPV) infection plays a significant role.
Most BCC patients were female, and this predominance was particularly significant for facial BCC. It is interesting to notice that, opposing this tendency, male sex was clearly predominant for BCC located in the torso, possibly revealing a higher level of UV exposure of this skin area in males than in females, imposed by the differences in sex-specific clothing habits. ${ }^{2}$ This male predominance was also verified for scalp BCC, and this is also probably justified by the difference in average hair length in both sexes, and eventually related to the higher incidence of alopecia androgenetica in men - having shorter, scarcer and thinner hair probably raises the risk of UV-induced carcinogenesis in the scalp. ${ }^{13}$ Additionally, the carcinogenic effect of X-ray therapy for tinea capitis, commonly used in children a few decades ago, must also be considered in some specific cases.

In SCC, male sex was significantly predominant on most locations, even though this predominance was not clearly observed in the general SCC population. Again, the lower lip and the genital area were the most representative examples, as smoking habits and HPV infections are more frequent in males than in females. Also, scalp and ear SCC affect males more frequently, due to the generally less protective male hair effect, opposing the female predominance observed for other facial SCC (as on the zygomatic and mandibular areas).$^{13}$ Female predominance was also observed for lower limb SCC, as this area is commonly exposed in females and not so often in males.

\section{CONCLUSION}

The described differences between BCC and SCC reinforce the fact that they represent distinct clinical entities, resulting from different etiopathologic pathways, and despite sharing common risk factors, they should be always considered separately. The evaluation of the epidemiologic characteristics of all malignant skin neoplasms, including NMSC, and its dynamic temporal changes, is therefore crucial for enhancing the effect of mass information campaigns and managing the available resources in Dermatology Departments, in order to control the increasing neoplasm numbers and promptly offer effective diagnostic and therapeutic procedures to an increasing oncologic population. 


\section{REFERENCES}

1. 1. Chinem VP, Miot HA. Epidemiology of basal cell carcinoma. An Bras Dermatol. 2011;86:292-305

2. 2. Dessinioti C, Antoniou C, Katsambas A, Stratigos AJ. Basal Cell Carcinoma: what's new under the Sun. Photochem Photobiol. 2010;86:481-91.

3. 3. Ferrándiz C, Fuente MJ, Ferrándiz L, Carrascosa JM. Basal Cell Carcinoma. Cancer Treat Res. 2009;146:263-78.

4. 4. Kyrgidis A, Tzellos TG, Vahtsevanos K, Triaridis S. New concepts for basal cell carcinoma. Demographic, clinical, histological risk factors, and biomarkers. A systematic review of evidence regarding risk for tumor development, susceptibility for second primary and recurrence. J Surg Res. 2010;159:545-56.

5. 5. Rubin Al, Chen EH, Ratner D. Basal-cell carcinoma. N Engl J Med. 2005;353:2262-9

6. 6. Situm M, Buljan M, Bulat V, Lugovic Mihic L, Bolanca Z, Simic D. The role of UV radiation in the development of basal cell carcinoma. Coll Antropol. 2008;32 Suppl 2:167-70.

7. 7. Diepgen TL, Mahler V. The epidemiology of skin cancer. Cr J Dermatol. 2002;146 Suppl 61:1-6

8. 8. Roewert-Huber J, Lange-Asschenfeldt B, Stockfleth E, Kerl H. Epidemiology and aetiology of basal cell carcinoma. Br J Dermatol. 2007;157 Suppl 2:47-51.

9. 9. Autier P, Boniol M, Doré JF. Sunscreen use and increased duration of intentional sun exposure: still a burning issue. Int J Cancer. 2007;122:1-5.

10. 10. Custódio G, Locks LH, Coan MF, Gonçalves CO, Trevisol DJ, Trevisol FS. Epidemiologia dos carcinomas basocelulares em Tubarao, Santa Catarina (SC), Brazil, entre 1999 E 2008. An Bras Dermatol. 2010;85:815-26

11. 11. Nunes $D H$, Back L, Vieira e Silva R, Medeiros VS. Incidência do carcinoma de células escamosas da pele na cidade de Tubarão (SC) - Brazil nos anos de 2000 , 2003 e 2006. An Bras Dermatol. 2009;84:482-8.

12. 12. Schmitt JV, Chinem VP, Marques ME, Miot HÁ. Increase in the incidence of basal cell carcinoma in a university hospital between 1999 and 2009. An Bras Dermatol. 2011;86:375-7.
13. 13. Rigel DS. Cutaneous ultraviolet exposure and its relationship to the development of skin câncer. J Am Acad Dermatol. 2008;58(5 Suppl 2): S129-32.

14. 14. Betti R, Inselvini E, Carducci M, Crosti C. Age and site prevalence of histologic subtypes of basal cell carcinomas. Int J Dermatol. 1995;34:174-6.

15. 15. Harris RB, Griffith K, Moon TE. Trends in the incidence of nonmelanoma skin cancers in southeastern Arizona, 1985-1996. J Am Acad Dermatol. 2001;45:528-36.

16. 16. Seretis K, Thomaidis V, Karpouzis A, Tamiolakis D, Tsamis I. Epidemiology of surgical treatment of nonmelanoma skin cancer of the head and neck in Greece. Dermatol Surg. 2010;36:15-22.

17. 17. Staples MP, Elwood M, Burton RC, Williams JL, Marks R, Giles GG. Non-melanoma skin cancer in Australia: the 2002 national survey and trends since 1985. Med J Aus. 2006;184:6-10.

18. 18. Weinstock MA. Death from skin cancer among the elderly: epidemiological patterns. Arch Dermatol. 1997;133:1207-9.

\author{
MAILING ADDRESS: \\ Pedro Andrade \\ Serviço de Dermatologia e Venereologia \\ Hospitais da Universidade de Coimbra, EPE \\ Praceta Mota Pinto \\ 3000-075 Coimbra Portugal \\ E-mail: pedro.andrade@portugalmail.com
}

How to cite this article: Andrade P, Brites MM, Vieira R, Mariano A, Reis JP, Tellechea O, Figueiredo A. Epidemiology of basal cell carcinomas and squamous cell carcinomas in a Department of Dermatology - a 5-year review. An Bras Dermatol. 2012;87(2):212-19. 